\title{
Postural Control and Functional Performance Changes with Inspiratory Muscle Training in Chronic Kidney Disease Patient
}

\author{
Rian Dewi Auriani ${ }^{1}$, Vitriana $^{1}$, Farida Arisanti $^{1}$
}

${ }^{1}$ Physical Medicine and Rehabilitation Department, Padjadjaran University, Hasan Sadikin General Hospital, Bandung, Indonesia.

\begin{abstract}
Introduction: Approximately $60-75 \%$ of chronic kidney disease (CKD) patients have a uremic syndrome that may cause damage to muscle cells, including the diaphragm as respiratory muscle, which is known involved in maintaining postural stability and balance. This study aims to see the effects of inspiratory muscle training on postural control and functional performance in CKD patients undergoing hemodialysis twice a week.
\end{abstract}

Methods: This single-blind randomized controlled trial enrolled 36 participants ( $45 \pm 9$ years) allocated randomly into the intervention and control group, receiving intensity of 50\% and $10 \%$ Maximum Inspiratory Pressure (MIP), respectively. Postural sway (95\% ellipse area, anteroposterior (AP), and mediolateral (ML) sway) measured using a force platform in static standing with feet apart (FP1) and together (FP2), and functional performance by Short Physical Performance Battery (SPPB), assessed at pre-and postintervention.

Results: After 8-week, intervention group demonstrated greater improvements on MIP (233.45\% vs $141.65 \% ; \mathrm{p}=0.0001$ ). Postural sway FP1 and FP2 not significantly improved in intervention group ( $\mathrm{p}>$ 0.05). The control group showed a significant increase $(p=0.007)$ in the SPPB score.

Conclusion: The inspiratory muscle training has not significantly improved postural control nor functional performance in patients with chronic kidney disease on hemodialysis. Further research is needed.

Keywords: chronic kidney disease, hemodialysis, inspiratory muscle training, physical performance, postural control 


\section{ABSTRAK}

Latar belakang: Sekitar $60-75 \%$ pasien dengan gagal ginjal kronis mengalami sindrom uremikum yang mungkin disebabkan oleh kerusakan sel-sel otot, termasuk diafragma sebagai salah satu otot pernapasan, yang diketahui terlibat daam pengaturan stabilitas postural dan keseimbangan. Penelitian ini bertujuan untuk mengetahui efek latiotot inspirasi pada kontrol postural dan keadaan fungsional pasien PGK selama menjalani hemodialisis dua kali dalam seminggu.

Metode: Artikel ini menggunakan metode uji coba acak terkontrol dengan melibatkan 36 peserta (45 \pm 9 tahun) yang dialokasikan secara acak ke dalam grup kontrol dan intervensi, masing-masing menerima sebanyak 50\% dan 10\% intensitas Tekanan Maksimum Inspirasi (TMI). Gerakan postural (95\% area ellipse, anteroposterior (AP), dan gerakan mediolateral (ML)) diukur menggunakan tahanan pijakan saat posisi berdiri dengan kaki terpisah (FP1) dan bersamaan (FP2), dan keadaan fungsional dengan menggunakan Short Physical Performance Battery (SPPB), dilakukan penilaian saat sebelum dan setelah intervensi.

Hasil: Setelah 8 minggu, grup intervensi menunjukkan lebih banyak perubahan pada TMI (233.45\% vs 141.65\%; $\mathrm{p}=0.0001)$. Gerakan postural FP1 dan FP2 tidak menunjukkan perubahan signifikan pada grup intervensi $(\mathrm{p}>0.05)$. Grup kontrol menunjukkan peningkatan signifikan $(\mathrm{p}=0.0007)$ pada skor SPPB.

Kesimpulan: Latihan otot inspirasi tidak menunjukkan perubahan yang signifikan pada kontrol postural maupun tampilan fungsional pada pasien dengan penyakit ginjal kronis yang menjalani hemodialisis. Dibutuhkan penelitian lanjutan.

Kata Kunci: hemodialisis, latihan otot inspirasi, kontrol postural, penyakit ginjal kronis, tampilan fisik

\section{Correspondent Detail:}

\section{Rian Dewi Auriani}

Email: r_dewi_a@yahoo.com

Physical Medicine and Rehabilitation

Department, Padjadjaran University, Hasan

Sadikin General Hospital,

Bandung, Indonesia.

\section{INTRODUCTION}

Chronic kidney disease (CKD) is characterized by alteration of the kidneys' structure or function that lasts more than three months and is classified into several stages based on the cause, glomerular filtration rate (GFR), and albuminuria. ${ }^{1}$ Chronic kidney disease is a global public health problem with an increasing prevalence and incidence and requires high financing. Based on Riset Kesehatan Dasar (RISKESDAS) in 2018, the prevalence of CKD in Indonesia increases from $0.2 \%$ in 2013 to $0.38 \%$ in 2018 . More than $30.56 \%$ of CKD patients undergoing hemodialysis (HD) are at a productive age (45-54 years old), causing productivity decline and socioeconomic losses due to the loss of productivity. ${ }^{2,3}$ One of CKD's systemic effects is uremic syndrome, which occurs in approximately $60-75 \%$ of CKD patients undergoing hemodialysis, affecting morbidity and mortality. ${ }^{4}$ 
Uremic syndrome is initiated by the systemic endothelial breakdown in the capillary system in the renal medulla, thus causing a gradual decline of GFR. The glomerular filtration rate can be found to be normal and irreversible in the early stage. However, as it develops, the compensation process will cause multiple sclerosis in the healthy endothelial layer, resulting in a progressive decline in the nephrons' function and cause the build-up of toxins and residual metabolism. ${ }^{5}$ Toxins accumulation in the body give toxic effects to mitochondria in muscle cells, called uremic myopathy. Uremic myopathy is a group of functional and morphological abnormalities consisting of muscular weakness (including muscle respiration), muscle wasting, endurance limitations, exercise intolerance, and fatigue, as well as uremic cardiomyopathy. ${ }^{6}$ Weakness and atrophy of the locomotor (extremities muscles) or non-locomotor (respiratory muscles) in CKD patients may affect posture and balance control. Changes in muscle morphology are indicated by a reduction in the number of capillaries per muscle fiber, comparable to the reduction of oxygen conduction. ${ }^{6}$ Inspiratory muscles, especially the diaphragm, play an essential role in the torso's stability and postural control by modulating the intraabdominal pressure, working collaboratively with the abdominal muscles, especially transverse abdominals, and pelvic floor muscles. Weak diaphragm muscles will prematurely fatigue and makes blood redirected away from peripheral and spinal muscles to enhance diaphragmatic circulation, causing a decrease of erector spina's muscle spindle sensitivity, decreasing core proprioception function as well as increasing the risk of injury. ${ }^{7,8}$
To improve the muscles of respiration, CKD patients are advised to do inspiratory muscle training. This exercise proves beneficial in increasing the pressure of maximum inspiration, the proprioception of cores, lung function, endurance, and training performance for several patients with heart and lung diseases, cardiac and chest surgery, multiple sclerosis, lower back pain, and stroke. ${ }^{9-12}$ Administration of aerobic exercises and resistances proves improvement of muscle strength, exercise capacity, functional capacity, inhibits systemic effects on cardiorespiratory and muscle system in CKD patients, thereby enhancing the quality of life, but did not produce improvements in postural control. ${ }^{13,14}$ We present here a hypothesis that the diaphragm strength are reduced among subjects, along with worse balance parameters. Inspiratory Muscle Training proved to be able to increase the thickness of the diaphragm muscle, and directly proportional to the increase in the strength of the inspiratory muscle. ${ }^{15}$ This study aims to examine the effects of inspiratory muscle strengthening exercises on postural control and balance in CKD patients who undergo HD twice a week.

\section{METHODS}

\section{Design}

This study is a single-blind randomized controlled trial (RCT), done by dividing the subject into two groups and used unpaired numerical categorical analysis. The minimum sample size was 18 per group, determined based on statistical calculations by setting a confidence level of $95 \%$ and a power test of $90 \%$. The intervention group got inspiratory 
muscle training (IMT) with an intensity of 50\% MIP (Maximum Inspiratory Pressure) and $10 \%$ MIP for the control group. Maximum inspiratory pressure was measured every 2 weeks, followed by dosage adjustments. IMT was performed for 8 weeks, 3 days a week, with 5 sets of 10 repetitions each, with oneminute rest between sets. The research took place in Hemodialysis Unit Al-Ihsan Hospital, West Java, between October - December 2019.

\section{Subjects}

All CKD patients who undergo HD performed consecutive sampling. The inclusion criteria are patient aged $45-54$ years, has a history of end-stage renal disease (ESRD) and has undergone HD twice a week for more than 3 months, able to perform an inspiratory muscle training (IMT) procedure, has a MIP value lower than $70 \%$ predicted measurement results using Carefusion MicroRPM, able to walk without an assistive device, able to understand oral and written instructions, cooperative and willing to participate in the research and able to do exercises by signing informed consent. Patients with comorbid such as obstructive pulmonary disease, pleural effusion, cardiomegaly, heart failure, or coronary heart disease, has a history of surgery on thoracic or abdominal in the last 6 months, have been given respiratory muscle training in the last 6 months, disorders of the eardrum and balance control, and anemia $(\mathrm{Hb}$ $<8 \mathrm{~g} / \mathrm{dL}$ ) excluded in the research. Patients who were clinically declining, not exercises $>3$ times during the training program, and resigned will be excluded from the study. The training session terminated if there is a decrease in consciousness/syncope, $\mathrm{SpO} 2<90 \%$, Borg Scale dyspnea $>7$, or an increase in pulse $>30$ bpm.

\section{Data collection}

The participants were divided into an intervention or control group. Maximum inspiratory pressure was measured 3 times. Then the averaged MIP value was used to determine the intensity of the exercises on each subject. At the next meeting, a postural sway assessment was conducted to assess postural control using the AMTI AccuPower force platform and an SPPB test in both groups. The postural sway examination is performed by setting the patient on a force plate, foot placed in 2 different positions (apart and together), both arms on the side, each for 30 seconds, then the data automatically recorded. Short Physical Performance Battery Assessment (SPPB) is done by asking subjects to stand for 30 seconds with legs in 3 different positions (closed, semi-tandem, and tandem), then walk 4 meters for 2 times (the fastest time is taken) and count the time when doing 5 times sit to stand up from the chair. At the end of the program ( $8^{\text {th }}$ week, after the $24^{\text {th }}$ exercise), the postural sway and SPPB test was reassessed.

\section{Data analysis}

The data were tested for their normality before undergoing analysis. We used an unpaired t-test for comparing the characteristics of the groups for normally distributed data and Mann Whitney test as an alternative. The paired t-test was used for comparing the analysis before and after the intervention. Statistical analysis of categorical data was tested with the Chisquare test. McNemar was used for comparing the categorical variables before and after the intervention. We used the significance of $\mathrm{P}$ $\leq 0.05$. The Data obtained is recorded in a particular form and then processed using SPSS version 24.0 for Windows. 


\section{RESULTS}

Forty-two CKD patients participated in the study, then divided into control and intervention groups. In the beginning, the control group had 22 subjects, then 4 were excluded because they did not attend the session three times in a row. The number of subjects in the intervention group was 20, but the same reason excluded 2 as the control group. Therefore, there were 18 patients in both groups.

During the training session, there were no dangerous side effects, such as decreased
$\mathrm{SpO}_{2}<90 \%$, Rated Perceived Exertion with Borg Scale $>7$, increased pulse $>30 \mathrm{bpm}$ from baseline, and decreased consciousness or syncope reported during the exercise.

\section{Subject characteristics}

The patient's average age in the intervention group is $44.67 \pm 7.98$ years, consisting of 5 males $(27.8 \%)$ and 13 females $(72.2 \%)$. The control group consisted of 4 male people $(22.2 \%)$ and 14 females (77.8\%). We found body weight, body mass index, and hemodialysis time significantly differed between both groups ( $P$ $=0.02,0.02$, and 0.03 , respectively). (Table 1$)$

Table 1. Subject characteristics

\begin{tabular}{|c|c|c|c|}
\hline \multirow[b]{2}{*}{ Variables } & \multicolumn{2}{|c|}{ Groups } & \multirow{2}{*}{$\begin{array}{c}P \text { value } \\
\text { between groups }\end{array}$} \\
\hline & $\begin{array}{c}\text { Intervention } \\
(\mathrm{n}=18)\end{array}$ & $\begin{array}{c}\text { Control } \\
(n=18)\end{array}$ & \\
\hline Age & & & 0.46 \\
\hline Range \pm std & $44.67 \pm 7.98$ & $46.89 \pm 10.01$ & \\
\hline Median & 46.00 & 49.50 & \\
\hline Gender & & & 1.00 \\
\hline Male & $5(27.8 \%)$ & $4(22.2 \%)$ & \\
\hline Female & $12(72.2 \%)$ & $14(77.8 \%)$ & \\
\hline Body weight (kgs) & & & $0.02 *$ \\
\hline Range \pm std & $58.78 \pm 10.48$ & $51.09 \pm 8.51$ & \\
\hline Median & 56.50 & 49.50 & \\
\hline Body height (meter) & & & 0.47 \\
\hline Range \pm std & $1.56 \pm 7.98$ & $1.54 \pm 0.10$ & \\
\hline Median & 1.55 & 1.53 & \\
\hline Body mass index $(\mathrm{kg} / \mathrm{m} 2)$ & & & $0.02 *$ \\
\hline Range \pm std & $24.12 \pm 4.05$ & $21.46 \pm 2.45$ & \\
\hline Median & 22.79 & 40.67 & \\
\hline Hemodialysis time & & & $0.03 *$ \\
\hline Range \pm std & $43.28 \pm 19.63$ & $31.11 \pm 19.20$ & \\
\hline Median & 48.00 & 24.50 & \\
\hline
\end{tabular}

* Significantly different $(\mathrm{P}$ value $\leq 0.05)$ 
Effect of IMT on the inspiratory muscle strength

The maximum inspiratory pressure (MIP) initial value is $33.17 \pm 20.33$. Based on data analysis, MIP's baseline value before and after the exercise between the intervention and control groups does not have a meaningful average difference. We found that the MIP value at the beginning and after IMT in both groups has significant differences $(\mathrm{P}=0.0001$ in both groups). We also found that the MIP difference between initial assessment and after IMT ( $\Delta$ MIP) in the intervention group was higher than the control group, but the increasing value and percentage of MIP were not statistically significant. $(\mathrm{P}=0.345$ and 0.443 respectively). (Table 2 )

Table 2. Effect of inspiratory muscle training toward maximum inspiratory pressure

\begin{tabular}{|c|c|c|c|}
\hline \multirow[b]{2}{*}{ Variables } & \multicolumn{2}{|c|}{ Groups } & \multirow[b]{2}{*}{$\begin{array}{c}P \text { value } \\
\text { between groups }\end{array}$} \\
\hline & $\begin{array}{c}\text { Intervention } \\
(n=18)\end{array}$ & $\begin{array}{c}\text { Control } \\
(n=18)\end{array}$ & \\
\hline MIP initial (cmH2O) & & & 0.443 \\
\hline Range \pm std & $33.7 \pm 20.33$ & $34.72 \pm 13.45$ & \\
\hline Median & 27.50 & 34.50 & \\
\hline Min-max & $9.00-75.00$ & $17.00-58.00$ & \\
\hline MIP after IMT (cmH2O) & & & 0.513 \\
\hline Range \pm std & $81.44 \pm 23.43$ & $76.39 \pm 22.41$ & \\
\hline Median & 83.00 & 70.50 & \\
\hline Min-max & $43.00-121.00$ & $44.00-122.00$ & \\
\hline$P$ value MIP & $0.0001 *$ & $0.0001 *$ & \\
\hline$\Delta \mathrm{MIP}$ & & & 0.345 \\
\hline Range \pm std & $81.44 \pm 23.43$ & $76.39 \pm 22.41$ & \\
\hline Median & 83.00 & 43.50 & \\
\hline Min-max & $13.00-98.00$ & $8.00-91.00$ & \\
\hline Increase of MIP (\%) & & & 0.443 \\
\hline Range \pm std & $233.45 \pm 233.07$ & $141.65 \pm 84.65$ & \\
\hline Median & 165.15 & 116.90 & \\
\hline Min-max & $43.30-890.90$ & $14.30-337.00$ & \\
\hline
\end{tabular}

MIP: maximum inspiratory pressure. IMT: inspiratory muscle training. $\triangle$ MIP, MIP differences between before and after IMT. * Significantly different $(\mathrm{P}$ value $\leq 0.05)$

\section{Effect of IMT training on postural control and functional performance \\ Force Plate}

The postural control assessment using the force plate was carried out in 2 different standing positions: FP1 (feet apart) and FP2 (feet together). There was no statistically significant difference between the two groups between $95 \%$ of the ellipse, ML, and AP areas in FP1 before the intervention but differed significantly after intervention. $(\mathrm{P}=0.001$, 0.007 , and 0.004 respectively). The numeric 
data analysis shows that the difference of $95 \%$ ellipse area, ML, and AP averages before and after the intervention on FP1 did not statistically significant in both groups. $(\mathrm{P}=0.001,0.007$, and 0.004 respectively). The numeric data analysis shows that the difference of average 95\% ellipse area, ML, and AP before and after the intervention on FP1 is not statistically significant in both groups.
The statistical test results in FP2 showed significantly different baseline in $95 \%$ ellipse area and ML sway between two groups before the intervention, and also no significant differences between groups after, except for ML sway $(p=0.031)$. Statistical results showed no significant differences in the $95 \%$ ellipse area, ML and AP areas in each group before and after the intervention. (Table 3 )

\begin{tabular}{|c|c|c|c|c|c|c|c|}
\hline \multirow{3}{*}{ Variables } & \multicolumn{6}{|c|}{ Table 3. Effect of IMT on postural control } & \multirow{3}{*}{$\begin{array}{l}P \text { value } \\
\text { between } \\
\text { groups }\end{array}$} \\
\hline & \multicolumn{3}{|c|}{ Intervention groups } & \multicolumn{3}{|c|}{ Control groups } & \\
\hline & Mean \pm SD & Median & Min-max & Mean \pm SD & Median & Min-max & \\
\hline \multicolumn{8}{|c|}{ Postural sway FP1 } \\
\hline \multicolumn{8}{|c|}{$95 \%$ ellipse area $(\mathrm{cm} 2)$} \\
\hline Before & $2.31 \pm 1.90$ & 1.85 & $0.33-7.64$ & $2.63 \pm 2.29$ & 2.14 & $0.56-9.30$ & 0.584 \\
\hline After & $2.06 \pm 0.96$ & 1.81 & $0.77-4.21$ & $3.32 \pm 1.31$ & 3.08 & $1.25-6.14$ & $0.001 *$ \\
\hline$P$ value & & 0.913 & & & 0.133 & & \\
\hline \multicolumn{8}{|l|}{$\mathbf{A P}(\mathrm{cm})$} \\
\hline Before & $1.76 \pm 1.40$ & 1.43 & $0.63-6.96$ & $1.69 \pm 0.85$ & 1.48 & $0.66-4.01$ & 0.628 \\
\hline After & $1.53 \pm 0.36$ & 1.42 & $0.97-2.26$ & $2.05 \pm 0.66$ & 1.88 & $0.99-3.35$ & $0.007 *$ \\
\hline$P$ value & & 0.777 & & & 0.048 & & \\
\hline \multicolumn{8}{|l|}{ ML (cm) } \\
\hline Before & $2.13 \pm 0.77$ & 1.91 & $1.06-4.49$ & $2.28 \pm 0.86$ & 2.30 & $0.39-4.17$ & 0.462 \\
\hline After & $2.07 \pm 0.47$ & 2.04 & $1.37-3.09$ & $2.62 \pm 0.60$ & 2.67 & $1.67-3.70$ & $0.004^{*}$ \\
\hline$P$ value & & 0.794 & & & 0.143 & & \\
\hline \multicolumn{8}{|c|}{ Postural sway FP2 } \\
\hline \multicolumn{8}{|c|}{$95 \%$ ellipse area $(\mathrm{cm} 2)$} \\
\hline Before & $4.43 \pm 2.65$ & 3.39 & $2.21-12.3$ & $5.94 \pm 2.49$ & 5.89 & $2.64-12.3$ & $0.019^{*}$ \\
\hline After & $4.35 \pm 1.76$ & 3.75 & $2.22-8.37$ & $5.43 \pm 3.32$ & 4.29 & $1.81-15.4$ & 0.481 \\
\hline$P$ value & & 0.679 & & & 0.327 & & \\
\hline \multicolumn{8}{|l|}{$\mathbf{A P}(\mathrm{cm})$} \\
\hline Before & $2,87 \pm 0.52$ & 2.83 & $2.21-4.06$ & $3.03 \pm 0.85$ & 2.87 & $1.87-4.91$ & $0.037^{*}$ \\
\hline After & $2.87 \pm 0.71$ & 2.88 & $1.67-4.39$ & $3.13 \pm 1.03$ & 2.88 & $1.95-4.59$ & $0.031^{*}$ \\
\hline$P$ value & & 0.991 & & & 0.983 & & \\
\hline \multicolumn{8}{|l|}{ ML (cm) } \\
\hline Before & $2.36 \pm 0.61$ & 2.18 & $1.67-3.94$ & $2.95 \pm 0.81$ & 2.81 & $0.39-4.17$ & 0.462 \\
\hline After & $2.27 \pm 0.43$ & 2.22 & $1.57-3.20$ & $2.70 \pm 0.63$ & 2.62 & $1.67-3.70$ & $0.004^{*}$ \\
\hline$P$ value & & 0.338 & & & 0.306 & & \\
\hline
\end{tabular}

FP1: foot apart. FP2 : foot together. AP: anteroposterior. ML: mediolateral. * Significantly different $(\mathrm{P}$ value $\leq 0.05)$ 


\section{SPPB}

There were no significant differences found in the SPPB score before the intervention between groups and after the intervention group treatment. However, we found a significant difference in the SPPB score before and after IMT in the control group $(\mathrm{P}=0.007)$. (Table 4)

Table 4. SPPB score before and after IMT

\begin{tabular}{|c|c|c|c|}
\hline \multirow[b]{2}{*}{ Variables } & \multicolumn{2}{|c|}{ Groups } & \multirow{2}{*}{$\begin{array}{c}P \text { value } \\
\text { between groups }\end{array}$} \\
\hline & $\begin{array}{c}\text { Intervention } \\
(\mathrm{n}=\mathbf{1 8})\end{array}$ & $\begin{array}{l}\text { Control } \\
(\mathrm{n}=18)\end{array}$ & \\
\hline SPPB score (before) & & & 0.059 \\
\hline Range \pm SD & $11.77 \pm 0.55$ & $10.83 \pm 1.62$ & \\
\hline Median & 12.00 & 11.50 & \\
\hline Min-max & $10.00-12.00$ & $7.00-12.00$ & \\
\hline SPPB score (after) & & & 0.791 \\
\hline Range \pm SD & $11.88 \pm 0.47$ & $11.77 \pm 0.73$ & \\
\hline Median & 12.00 & 11.50 & \\
\hline Min-max & $10.00-12.00$ & $9.00-12.00$ & \\
\hline$P$ value SPPB & 0.157 & $0.007 *$ & \\
\hline$\Delta$ SPBB score & & & $0.031 * *$ \\
\hline Mean \pm Std & $0.11 \pm 0.323$ & $0.94 \pm 1.305$ & \\
\hline Median & 0.00 & 0.50 & \\
\hline Range (min-max) & $0.00-1.00$ & $0.00-5.00$ & \\
\hline Increase of SPBB score & & & $0.029 * *$ \\
\hline Mean \pm Std & $0.01 \pm 0.029$ & $0.11 \pm 0.177$ & \\
\hline Median & 0.00 & 0.05 & \\
\hline Range (min-max) & $0.00-0.09$ & $0.00-0.71$ & \\
\hline
\end{tabular}

SPPB : short physical performance battery. ${ }^{*}$ Significantly different $(\mathrm{P} \leq 0.05)$

\section{DISCUSSION}

This study's average age was $45.77 \pm 8.99$ years, ranging between $30-59$ years. This result is consistent with the conditions in Indonesia that refer to hospital information system data (SIRS), that most patients with CKD who undergo HD in Indonesia ranging in the 45-54 years old. ${ }^{16,17}$ As the age increased, it will affect balance due to 1) morphological changes and physiological functions of sensory structures,
2) loss of receptor and large myelinated sensory fibers in the distal region, and 3) disruption of proprioception, vibration, discrimination, and balance. The presence of comorbid causes disruption of effector efficiency, which is in the form of muscle atrophy, tendon flexibility, and the presence of bone deformities. ${ }^{18}$

The body mass index positively correlates with postural sway and causes postural imbalance. Higher BMI and fat percentage significantly 
increase the risk of falls and decrease dynamic balance test results. ${ }^{19.20}$ Reese et al. showed that BMI below $35 \mathrm{~kg} / \mathrm{m}^{2}$ did not significantly affect balance. ${ }^{21}$ Alonso et al. stated that gender did not affect postural balance, but anthropometry (height) in men was more influential than women. In contrast, Kejonen et al. found no relationship between anthropometric factors with variations in movement in maintaining body balance while standing. ${ }^{22,23}$ BMI difference in this study is caused more by a significant difference in body weight, not by height, so it supports that anthropometric differences will not affect the balance.

There were no significant differences in the initial values of MIP, SPPB, and postural sway FP1. There is no specific research comparing the balance condition to the length of time undergoing hemodialysis. Barzegar et al., in their study, stated that there was no correlation between the duration of hemodialysis and quality of life as assessed by KDQOL. Allegedly with increasing periods undergoing $\mathrm{HD}$, patients have adapted to the HD process and experience improvement in symptoms due to uremia. ${ }^{24}$

\section{Maximum Inspiratory Pressure (MIP)}

A reference value of respiratory muscle strength in healthy and ill populations in Indonesia does not yet exist, so this study uses predictive reference values from systematic reviews based on the journals that take MIP measurements in North America, Brazil, Sweden, the Netherlands, and India. This study's subjects had a baseline MIP value lower than 70\% predicted value based on the age group. ${ }^{25}$ Previous study done by Sachs et al. in America comparing the value of MIP in non-Hispanic, African American, and Asian (Chinese) races shows no significant difference in inspiratory muscle strength between the races. ${ }^{26}$

Maximum Inspiratory Pressure assessment was carried out after 8 weeks of intervention. Both groups experienced a significant increase in MIP scores, but the difference did not differ significantly between them. The average increase in MIP in the intervention group was 48.27 points (up 165.15\%), while in the control group, it was 41.66 points (up $116.9 \%)$. This result was found similar to the study by Ferraro et al., in which an increase in MIP was found significant in the intervention group (load intensity $50 \%$ of the MIP) and in the control group (15\% of MIP). There were no statistically significant differences in increment difference in the two groups. The increase in MIP in the control group is thought to be caused by the physiological effects of strengthening exercises that occur in increased neural activation rather than due to changes in muscle structure. ${ }^{11}$

Based on this theory, it can be assumed that the increase in MIP value in the intervention group is also partly due to an increase in neural activation. Several studies have demonstrated the effect of IMT on diaphragm muscle thickness in healthy people, the elderly, and stroke patients. These exercises were carried out for 8 weeks, each using different intensities and frequencies, and all of them showed an increase in MIP value accompanied by an increase in diaphragm muscle thickness. ${ }^{15,27,28}$ Kocjan et al. using other functional parameters of the diaphragm, closely related to its strength, found that greater values of diaphragm inspiratory thickness, diaphragm thickness fraction and diaphragm movement 
were associated with shorter path length and smaller ellipse field. ${ }^{12}$

The dose of exercise given in this study was almost the same as the exercise dose performed by Mills et al., for the elderly group, namely $50 \%$ of the MIP dose, for 8 (eight) weeks, 60 repetitions per day, performed every day. This dose increased the MIP value by $34 \%$ and increased diaphragm thickness by $38 \%{ }^{27}$ The increase of MIP in this study $(233 \%$ in the intervention group and $141 \%$ in the control group) was greater than the increase in MIP in the Dipp et al. study (33.5\%) with an IMT dose of 6 (six) times a week for 5 (five) weeks, performed at home and intradialytic in the hospital, with a gradual increase in intensity ranging from $50 \%$ to $70 \%$ MIP. The baseline MIP score of the subjects in Dipp et al. research was $70 \%$ of the predicted value, whereas in these studies the mean MIP value was only 25-30\% (range 10-60\%) of the predicted value and increased to $60-80 \%$ of the value. predictions. (range 40-95\%). The baseline difference may be one reason for the high percentage increase in this study. ${ }^{29}$

\section{Postural sway}

The postural sway baseline between the intervention and control groups measured in the open feet position (FP1) was not significantly different. Reassessment after 8 weeks of IMT showed a reduction in sway area and anteroposterior sway or mediolateral sway in the intervention group, but not statistically significant. The control group has worse result, but the value was not significant except in the anteroposterior plane, so the differences between groups after the intervention became significant. IMT exercise impacted the control and intervention groups, and it was seen that higher doses had better effects than lower doses.
The postural sway baseline between the measurement groups with closed feet (FP2) was significantly different among the sway area and the mediolateral sway. After training, postural sway assessment showed improvement in the sway area and mediolateral sway both in the intervention and control groups, but this increase was not statistically significant. The control group experienced a greater deterioration in the anteroposterior plane, but the value was also not significant. Balance assessment with closed feet (FP2) shows greater anteroposterior and mediolateral sway than FP1. These results are consistent with previous research, which states that reducing the base of support will challenge the balance function. The most significant difference is seen in anteroposterior sway (FP2> FP1), this is following the statement of Chiari et al., which mentions that anteroposterior sway will be more stable when the foot is in an open position.30 Our study found that anteroposterior sway values in the control group were worsened in FP1 and FP2, and AP sway in FP2 in the intervention group. This exercise improves the direction of mediolateral movement better than anteroposterior movement.

The results we obtained were contrary to several previous studies by Kocjan et.al, Lee et.al, \& Morilla et.al. Kocjan et al. using other functional parameters of the diaphragm, closely related to its strength, found that greater values of diaphragm inspiratory thickness, diaphragm thickness fraction and diaphragm movement were associated with shorter path length and smaller ellipse field. ${ }^{12}$ In stroke patients, Lee et al., found improvements in the stability limits of the CoP after training of the respiratory muscles. ${ }^{31}$ Morillas et al. show 
that the greater the inspiratory muscle strength, the less displacement of the pressure center, while at higher respiratory rates there is greater displacement. ${ }^{32}$

\section{Short Physical Performance Battery (SPPB)}

The SPPB test is recommended by Tasoglu et al. as an instrument of functional performance testing in CKD patients, which must be done at an early stage of CKD and then routinely carried out to evaluate the decline in functional ability over time. ${ }^{33,34}$ The SPPB baseline score in this study did not differ significantly between the intervention and control groups (11.78 vs. 10.83). This finding shows that HD patients in this study had a better baseline of physical performance than patients in a previous study by Reese et al., of 1111 patients with non-HD CRF who found an average SPPB score 8.3. Similarly, this study also had a higher SPPB score when compared with the baseline of Kwon et al. (SPPB score 5.6) Kaysen et al. (SPPB score 8.35 specifically for patients $\mathrm{CKD}$ with hemodialysis), Hartmann et al., (SPPB score of 8.35), and Nogueira et al., (SPPB 9 score). It can be the reason for the results of this study were not significant compared to the previous study. ${ }^{21,35-38}$

This study found that SPPB scores on the static balance component were almost all good; low-value scores were found on the dynamic component, which was sit-to-stand 5 times. Previous studies by Sieńko-Awierianów et al. showed that dynamic balance dysfunction significantly emerged precede static balance dysfunction, beginning at the age of $50 .{ }^{19}$ The increase in SPPB scores in the control group had significant value. In contrast, the intervention group was smaller and not statistically significant. This might have happened because the treatment group's SPPB base score approached the maximum value, resulting in a "ceiling effect." The increase in SPPB scores in this study was more significant than in the Kwon et al. Study, which provided an OTAGO Exercise Program for CKD patients for 12 weeks, namely in the control group 0.94 vs. 0 points, and the intervention group 0.1 vs. 0.07 points. ${ }^{35}$ Another exercise intervention assessing SPPB changes in CKD on HD patients was carried out by Chen et al., such as providing leg strengthening exercises and an increase in SPPB score significantly, which is 2 points in the intervention group. 39 This study was conducted on subjects aged 69 years on average and baseline scores SPPB in the intervention and control groups were 5 and 6 , respectively lower than the SPPB baseline score in this study.

\section{Limitations}

This study did not include other factors that can affect the postural balance, such as limb muscle strength, other core muscle strength, sensory function, or proprioception. It also lacks uniformity of the foot's opening angle that may affect the measurement results. Additionally, balance checks were only performed in a static position, thus making the examination results of the impact of IMT training less accurate. The wide age range in this study and no age classification because of the limited number of samples causing comparison between age groups and further analysis regarding the correlation of a significant increase in MIP on postural sway and SPPB score in various age groups could not be made. We also did not monitor each subject's activities during the research period, so that it can be a confounding factor that influences the result. 


\section{CONCLUSIONS}

Inspiratory muscle training increases MIP, but has not significantly improved postural control or functional performance in patients with CKD. Inspiratory muscle training is more likely to impact postural control in the mediolateral direction, although it is not significant, thus this study also cannot prove that increasing inspiratory muscle strength can improve balance.

It is necessary to examine other factors that affect postural control, such as limb muscle strength, other core muscle strength, sensory function, proprioception, and cognition. It is necessary to standardize the foot's position when measuring postural sway using force plates and adding the type of postural challenge given. It also needs to do further research related to the optimal training dose and the effect of inspiratory muscle strengthening exercises on the balance of patients with chronic kidney failure based on age group, duration of illness, and body weight and monitoring the subject's activities during the training process.

\section{REFERENCES}

1. KDIGO. Clinical practice guideline for the evaluation and management of chronic kidney disease. Kidney Int 2013; 84(3): 622-3.

2. Kementerian Kesehatan Republik Indonesia (Kemenkes RI). Hasil Riset Kesehatan Dasar (Riskesdas) 2013. Jakarta: Balitbang; 2013

3. Kementerian Kesehatan Republik Indonesia (Kemenkes RI). Hasil Riset
Kesehatan Dasar (Riskesdas) 2018. Jakarta: Balitbang; 2018

4. Bhadauria D, Agarwal N. Uremic myopathy. Clinical Queries: Nephrology 2012; 1: 279-83.

5. Foris LA, Bashir K. Uremia. Treasure Island (FL) : StatPearls Publishing. 2018.

6. Kaltsatou A, Sakkas GK, Poulianiti KP, Koutedakis Y, Tepetes K, Christodoulidis $\mathrm{G}$ et al. Uremic myopathy: is oxidative stress implicated in muscle dysfunction in uremia? Front Physiol 2015; 6 .

7. Keles MN, Elbasan B, Apaydin U, Aribas Z, Bakirtas A, Kokturk N. Effects of inspiratory muscle training in children with cerebral palsy: a randomized controlled trial. Braz J Phys Ther 2018; 22: 493-501.

8. Koláŕ P, Šulc J, Kynčl M, Šanda J, Čakrt $\mathrm{O}$, Andel $\mathrm{R}$ et al. Postural function of the diaphragm in persons with and without chronic low back pain. J Orthop Sports Phys Ther 2012; 42: 352-62.

9. Bosnak-Guclu M, Arikan H, Savci S, InalInce D, Tulumen E, Aytemir K et al. Effects of inspiratory muscle training in patients with heart failure. Respir Med 2011; 105: 1671-81.

10. Oh D, Kim G, Lee W, Shin MMS. Effects of inspiratory muscle training on balance ability and abdominal muscle thickness in chronic stroke patients. J Phys Ther Sci 2016; 28: 107-11.

11. Ferraro FV, Gavin JP, Wainwright $T$, McConnell A. The effects of 8 weeks of inspiratory muscle training on the balance of healthy older adults: a randomized, double-blind, placebo-controlled study. Physiol Rep 2019; 7: e14076.

12. Kocjan J, Gzik-Zroska B, Nowakowska K, Burkacki M, Suchoń S, Michnik R et al. 
Impact of diaphragm function parameters on balance maintenance. Plos One 2018; 13: e0208697.

13. de Medeiros AIC, Fuzari HKB, Rattesa C, Brandão DC, de Melo Marinho PÉ. Inspiratory muscle training improves respiratory muscle strength, functional capacity and quality of life in patients with chronic kidney disease: a systematic review. J Physiother 2017; 63: 76-83.

14. Carletti CO, Rosa CS da C, Souza GD e, Ramirez AP, Daibem CGL, Monteiro HL. Intradialytic exercise and postural control in patients with chronic kidney disease undergoing hemodialysis. Fisioter em Mov 2017; 30: 247-54.

15. Souza H, Rocha T, Pessoa M, Rattes C, Brandao D, Fregonezi $G$ et al. Effects of inspiratory muscle training in elderly women on respiratory muscle strength, diaphragm thickness and mobility. $\mathrm{J}$ Gerontol A Biol Sci Med Sci 2014; 69: 1545-53.

16. Perkumpulan Nefrologi Indonesia (Pernefri)10th Report on Indonesian Renal Registry 2017.

17. Pusat Data dan Informasi Kementrian Kesehatan RI. Infodatin : Situasi Penyakit Ginjal Kronis. 2017.

18. Springhetti I, Villani C. Balance Rehabilitation Using Computerized Dynamic Posturographic Platforms. In: Sandrini G, Homberg V, Saltuari L, Smania N, Pedrocchi A (eds). Advanced Technologies for the Rehabilitation of Gait and Balance Disorders. Springer International Publishing: Cham 2018 pp 95-120.

19. Sieńko-Awierianów E, Lubkowska A, Kolano P, Chudecka M. Postural stability and risk of falls per decade of adult life - a pilot study. Anthropol Rev 2018; 81: 102-9.

20. Hue O, Simoneau M, Marcotte J, Berrigan F, Doré J, Marceau P et al. Body weight is a strong predictor of postural stability. Gait Posture 2007; 26: 32-8.

21. Reese PP, Cappola AR, Shults J, Townsend $\mathrm{RR}$, Gadegbeku CA, Anderson C et al. Physical performance and frailty in chronic kidney disease. Am J Nephrol 2013; 38: 307-315.

22. Alonso A, Luna N, Mochizuki L, Barbieri F, Santos S, D'Andreia Greve J. The influence of anthropometric factors on postural balance: the relationship between body composition and posturographic measurements in young adults. Clinics 2012; 67: 1433-41.

23. Kejonen P. Kauranen K, Vanharanta H. The relationship between anthropometric factors and body balancing movements in postural balance. Arch Phys Med Rehabil 2003; 84: 17-22.

24. Barzegar H, Jafari H, Yazdani Charati J, Esmaeili R. Relationship between duration of dialysis and quality of life in hemodialysis patients. Iran J Psychiatry Behav Sci 2017; 11.

25. Pessoa IS, Parreira VF, Fregonezi G, Chung F. Reference values for maximal inspiratory pressure: A systematic review. Can Respir J 2014; 21(1): 43-50

26. Sachs MC, Enright PL, Stukovsky KH, Jiang R, Barr RG. Performance of maximal inspiratory pressure tests and MIP reference equations for four ethnic groups. Respir Care 2009; 54(10): 1321-28

27. Mills DE, Johnson MA, Barnett YA, Smith WHT, Sharpe GR. The effects of inspiratory 
muscle training in older adults: Med Sci Sports Exerc 2015; 47: 691-7.

28. Jung J-H, Kim N-S. Effects of inspiratory muscle training on diaphragm thickness, pulmonary function, and chest expansion in chronic stroke patients. J Korean Soc Phys Med 2013; 8: 59-69.

29. Dipp T, Macagnan FE, Schardong J, Fernandes RO, Lemos LC, Plentz RDM. Short period of high-intensity inspiratory muscle training improves inspiratory muscle strength in patients with chronic kidney disease on hemodialysis: a randomized controlled trial. Braz J Phys Ther 2020; 24: 280-6.

30. Chiari L, Rocchi L, Cappello A. Stabilometric parameters are affected by anthropometry and foot placement. Clin Biomech 2002; 17: 666-77.

31. Lee K, Park D, Lee G. Progressive respiratory muscle training for improving trunk stability in chronic stroke survivors: A pilot randomized controlled trial. J Stroke Cerebrovasc Dis 2019; 28: 1200-11.

32. León-Morillas F, Lozano-Quijada C, Lérida-Ortega MÁ, León-Garzón MC, Ibáñez-Vera AJ, de Oliveira-Sousa SL. Relationship between respiratory muscle function and postural stability in male soccer players: A case-control study. Healthcare 2021; 9: 644.

33. Taşoğlu Ö, Bayrakci N, Özcan DS, Özkayar N, Taşoğlu İ, ÖzgiRgiN N. A functional tool demonstrating the physical function decline independent of age in patients with predialysis chronic kidney disease. Turk $\mathrm{J}$ Med Sci 2017; 47(1): 91-7.

34. Ortega-Pérez de Villar L, Martínez-Olmos FJ, Junqué-Jiménez A, Amer-Cuenca JJ, Martínez-Gramage J, Mercer T et al. Test- retest reliability and minimal detectable change scores for the short physical performance battery, one-legged standing test and timed up and go test in patients undergoing hemodialysis. PLoS One 2018; 13 (8).

35. Kwon A, Mackey D, Feldman F, Parson T. Evaluation of an exercise program delivered prior to hemodialysis. Simon Fraser University. 2019. Available from: https://www.semanticscholar.org/paper/ Evaluation-of-an-exercise-programdelivered-prior-Kwon/2370cecdc9ea5abaa 8daee956eafb6bf657aa25a

36. Kaysen GA, Larive B, Painter P, Craig A, Lindsay RM, Rocco MV et al. Baseline physical performance, health, and functioning of participants in the frequent hemodialysis network (FHN) trial. Am J Kidney Dis 2011; 57: 101-12.

37. Hartmann EL, Kitzman D, Rocco M, Leng $\mathrm{X}$, Klepin H, Gordon M et al. Physical function in older candidates for renal transplantation: An impaired population. CJASN 2009; 4: 588-94.

38. Nogueira Á, Álvarez G, Russo F, San-José B, Sánchez-Tomero JA, Barril G. Is SPPB useful as a method for screening functional capacity in patients with advanced chronic kidney disease? Nefrología (English Edition) 2019; 39: 489-96.

39. Chen JLT, Godfrey S, Ng TT, Moorthi R, Liangos O, Ruthazer R et al. Effect of intradialytic, low-intensity strength training on functional capacity in adult haemodialysis patients: a randomized pilot trial. Nephrol Dial Transplant 2010; 25: 1936-43. 